\title{
HUBUNGAN SPIRITUALITAS DENGAN STRES LANSIA DI PUSKESMAS PAKJO PALEMBANG
}

\author{
Dheni Koerniawan ${ }^{1}$, Uci Candrawulan ${ }^{2}$ \\ Program Studi Ilmu Keperawatan dan Ners Fakultas Ilmu \\ Kesehatan Universitas Katolik Musi Charitas
}

\begin{abstract}
ABSTRAK
Latar Belakang : Lansia dalam proses menua mengalami penurunan fisiologis serta kehilangan dan berduka. Hal tersebut membuat lansia rentan mengalami stres. Kondisi stres yang dialami dapat membuat lansia menjadi tidak produktif dan fokus terhadap proses kehilangannya. Stres dapat menyebabkan hilangnya minat, merasa gagal, serta kelelahan fisik dan emosional sehingga mengakibatkan kemarahan, ansietas, depresi, gejala patologis, bahkan gangguan jiwa. Oleh karena itu, diperlukan cara yang efektif dalam manajemen stres yang dialami oleh lansia. Manajemen keperawatan dalam menangani stres dapat dilakukan dengan pendekatan holistik yang salah satunya melalui asuhan spiritual. Keyakinan yang kuat dapat menimbulkan efek kuat yang positif terhadap pikiran dan tubuh sehingga memberikan rasa nyaman.

Tujuan : Penelitian ini bertujuan untuk mengetahui hubungan spiritualitas dengan stres lansia di. Palembang

Metode : Desain survei analitik dengan pendekatan potong lintang dilakukan terhadap 72 responden yang diambil secara purposif. Data diambil menggunakan Religious Comittment Inventory (RCI) dan Perceived Stress Scale (PSS) yang kemudian dianalisis menggunakan korelasi Pearson's.

Hasil : Hasil studi menunjukkan bahwa rerata skor RCI 31,03 (tingkat spiritualitas sedang) dengan standar deviasi 7,551 dan PSS 20,47 (tingkat stres sedang) dengan standar deviasi 5,642. Hasil bivariat menunjukkan adanya hubungan negatif yang signifikan antara spiritualitas dengan stres $(r=-0,267 ; p=0,023)$.

Kesimpulan : Oleh karena itu, asuhan keperawatan holistik dengan pendekatan spiritual dapat dilakukan oleh perawat dalam edukasi pada lansia sehingga dapat meningkatkan spiritualitasnya sebagai manajemen stres yang positif dan efektif dengan meningkatkan ibadah, frekuensi mempelajari kitab suci, dan interaksi sosial dengan orang lain dalam konteks kegiatan keagamaan yang positif.
\end{abstract}

\section{Kata Kunci: Lansia, Spiritualitas, Stres, Hubungan}

\begin{abstract}
Bacground: Elderly in aging process experienced physiological decline and loss and grieving. This can make elderly vulnerable to stress. Stress can make elderly not productive and focus on his/her losing. Stress might causes loss of interest, feelings of failure, and restless in physically and emotionally. Stress can impact to anger, anxiety, depression, pathological symptoms, and psychiatric illness. Thus, it require effective ways to manage stress which is experienced by older adults. Nursing management in handling stress can be done with holistic approach which one is spiritual care. Strong belief can make powerful positive effect to mind and body and can bring comfort.

Goals : This study aim to know the relationship between spirituality with stress elderly in Palembang.

Methods: Survey analytic design with cross sectional approach had done to 72 respondents by purposive. Data have been taken by Religious Commitment Inventory (RCI) and Perceived Stress Scale (PSS) then analyzed by Pearson's correlation.

Results : Results showed mean of RCI 31,03 (moderate religious) with standard deviation 7,551 and PSS mean 20,47 (moderate stress level) with standard deviation 5,642. Bivariate
\end{abstract}


result showed there was negative relationship between spirituality and stress ( $r=-0,267 ; p=$ $0,023)$.

Conclusion: Therefore, holistic nursing care with spiritual approach can be done by nurse in education to elderly so they can enhance their spirituality as positive and effective stress management with more intense praying, increase holy scripture learning and social interaction with other people with positive religious practice and activity.

\section{Keywords: Elderly, Spiritualitas, Stress, Relationship}

\section{PENDAHULUAN}

Lansia sebagai tahapan tumbuh kembang akhir manusia yang dalam prosesnya mengalami penurunan fungsi fisiologis sehingga produktivitasnya juga ikut menurun. Oleh karena itu, lansia banyak mengalami kehilangan karena penurunan fungsi tersebut seperti kehilangan pekerjaan, aktivitas menjadi berkurang, dan pemenuhan kebutuhan sehari-hari memerlukan bantuan orang lain. Selain itu, lansia juga mengalami kehilangan akibat kematian pasangan.

Indonesia pada tahun 2012 memiliki proporsi penduduk lansia sebanyak 7,56\% (Litbangkes Kemenkes RI, 2013) sedangkan pada tahun 2017 sebanyak 23,66 juta $(9,03 \%)$ dan diperkirakan pada tahun 2020 menjadi 27,08 juta, tahun 2025 menjadi 33,69 juta, dan tahun 2030 menjadi 40,95 juta (Kemenkes RI, 2017). Sedangkan Sumatera Selatan berada pada peringkat ketujuh penduduk lansia terbanyak di Indonesia $(9,18 \%)$ (Kemenkes RI, 2017). Produktivitas lansia yang menurun dapat menjadi beban ekonomi yang perlu ditanggung oleh penduduk usia produktif. Hal ini terproyeksi dari indeks rasio ketergantungan penduduk lansia dalam aspek ekonomi dari $12,71 \%$ pada tahun 2014 menjadi 13,28\% pada tahun 2015 (Kemenkes RI, 2017).

Proses kehilangan yang dialami lansia menjadi predisposisi lansia mengalami stres yang jika tidak dilakukan manajemen dengan baik, maka lansia akan mengalami mekanisme koping yang adaptif dan kemudian dapat berkembang menjadi depresi. Roy dalam model adaptasinya memfokuskan pada keterhubungan empat sistem adaptif, yaitu fisiologis, konsep diri, peran, dan ketergantungan (McEwen \&
Wills, 2011), yang merupakan bagian dalam dua subsistem mekanisme koping, yaitu regulator (mekanisme koping fisiologis: sistem mural, kimia, endokrin) dan kognator (mekanisme koping kognitifemosi: persepsi dan informasi, pembelajaran, penilaian, dan emosi) (Alligood, 2014).

Stres atau trauma yang terjadi selama proses perkembangan dapat mengakibatkan tiga kondisi, yaitu perubahan persepsi diri, perubahan hubungan dengan orang lain, serta perubahan filosofis mengenai prioritas, apresiasi, dan spiritualitas.Penurunan produktivitas dan stres merupakan proses resiprokal (timbal balik yang berkelanjutan) sehingga ketika lansia merasa sangat bergantung pada orang lain, maka lansia akan mengalami stres karena merasa tidak lagi mampu mengerjakan sesuatu secara mandiri. Oleh karena itu, stres yang dialami lansia terutama pada lansia yang mengalami penyakit penyerta dapat memperburuk kondisi stres yang sudah atau sedang dialaminya.

Lansia pada masa tuanya ketika kesibukan sehari-harinya berkurang, sudah mulai melakukan pendekatan spiritual seperti beribadah lebih sering, mempelajari konsep dan kitab suci agama yang diyakininya, dan mengikuti kegiatan di lingkungannya. Manusia cenderung kembali kepada apa yang diyakininya ketika muncul pertanyaan pada dirinya sebagai hasil dari penderitaan yang dialaminya.Begitu juga ketika manusia semakin menua dan menjadi lansia. Lansia cenderung mempertanyakan apa makna dari apa yang sedang dialaminya atau apa yang akan dialaminya setelah kematian.

Religiusitas dan spiritualitas merupakan sebuah aspek multidimensional 
yang melibatkan kognisi, perasaan, dan perilaku termasuk aspek positif dan negatif dari relasi antara individu dengan Sang Pencipta(Werdel et al., 2014).Komitmen yang jelas dan kuat dapat membuat individu mampu memperkuat kemampuan dan kecerdasan spiritualnya dengan memaknai apa arti dirinya dilahirkan, ditempatkan, dan tujuan dirinya berada di dunia ini. Komitmen tersebut memampukan individu berupaya mempelajari secara intrapersonal dan interpersonal dan meningkatkan iman dan keyakinan terhadap agama atau kepercayaan yang dianutnya. Pemahaman yang mendalam secara spiritual membuat individu lebih mampu beradaptasi terhadap stresor dan memiliki mekanisme koping yang lebih baik.

Spiritualitas membuat individu memiliki kemampuan transenden dalam berespon terhadap peristiwa yang terjadi sepanjang hidupnya. Proses transendensi tersebut terjadi karena individu memiliki keyakinan diri (self-compassion) yang baik sehingga dapat memiliki mekanisme koping yang lebih baik $(p<0,001)$ (Perez-Blasco et al., 2016). Oleh karena itu, penelitian ini bertujuan untuk mengetahui hubungan spiritualitas dengan stres lansia di Puskesmas Pakjo Palembang.

\section{METODE PENELITIAN}

Penelitian ini menggunakan desain survei analitik dengan pendekatan potong lintang. Populasi penelitian adalah 118 lansia yang mengujungi Puskesmas Pakjo dan kemudian diambil secara purposif dan besar sampel dihitung dengan rumus Slovin. Sampel terdiri dari 63 responden ditambah dengan sampling eror $13 \%$ sehingga jumlah sampel keseluruhan menjadi 72 responden yang dipilih dengan teknik purposive sampling berdasarkan kriteria inklusif: lansia yang berusia $45-74$ tahun, bertempat tinggal di kelurahan Pakjo, serta dapat membaca dan menulis; sedangkan kriteria eksklusifnya adalah lansia yang mengalami gangguan penglihatan pendengaran dan tidak bersedia menjadi responden.

Seluruh data diambil menggunakan kuesioner. Variabel spiritualitas diukur menggunakan Religious Comittment Inventory $(R C I)$ yang terdiri dari 10 butir dan memiliki dua dimensi, yaitukomitmen intrapersonal dan interpersonal(Conner, 2012). $R C I$ memiliki validitas yang baik dengan rentang koefisien korelasi 0,5440,713 dan reliabilitas 0,831 . Sedangkan variabel stres diukur dengan Perceived Stress Scale (PSS) terdiri dari 10 butir. Validitas PSS berada pada rentang 0,5070,621 dan reliabilitas sebesar 0,75 .

Analisis data univariat menggunakan ukuran pemusatan dan disajikan dalam rerata/mean dan simpangan baku/standar deviasi. Sedangkan uji korelasi Pearson's digunakan untuk analisis bivariat.

\section{HASIL PENELITIAN}

\section{Analisis Univariat}

Tabel 1.1 Hasil analisis deskriptif spiritualitas dan stres pada lansia di Puskesmas Pakjo Palembang

\begin{tabular}{lcc}
\hline \multicolumn{1}{c}{ Variabel } & Mean & $\begin{array}{c}\text { Standar } \\
\text { deviasi }\end{array}$ \\
\hline Spiritualitas $(R C I)$ & 31,03 & 7,551 \\
Stres $(P S S)$ & 20,47 & 5,642 \\
\hline
\end{tabular}

Tabel 1.1 memperlihatkan bahwa rerata tingkat spiritualitas lansia di Palembang berada di tingkat sedang (skor 22-37) dengan simpangan baku sebesar 7,551. Sedangkan rerata tingkat stres lansia berada pada tingkat sedang (skor 14-27) dengan simpangan baku 5,642. Hasil analisis univariat menunjukkan bahwa variasi skor spiritualitas berada pada rentang 23,479 hingga 38,581 dan skor stres berada pada rentang 14,828 hingga 26,112 .

\section{Analisis Bivariat}

Tabel 1.2 Hasil analisis Pearson's antara spiritualitas dengan stres pada lansia di Puskesmas Pakjo Palembang

\begin{tabular}{lcc}
\hline \multicolumn{1}{c}{ Variabel } & $\begin{array}{c}\text { Koefisien } \\
\text { korelasi }(\boldsymbol{r})\end{array}$ & $\boldsymbol{p}$-value \\
\hline $\begin{array}{l}\text { Spiritualitas } \\
\text { Stress }\end{array}$ & $-0,267$ & 0,023 \\
\hline
\end{tabular}


Hasil analisis bivariat pada tabel 1.2 menunjukkan bahwa terdapat hubungan yang signifikan antara spiritualitas dengan stres $(p=0,023)$. Hubungan ini bersifat negatif dengan tingkat korelasi lemah ( $r=-$ $0,267)$. Oleh karena itu, dapat disimpulkan bahwa semakin tinggi tingkat spiritualitas lansia maka akan semakin rendah tingkat stresnya.

\section{PEMBAHASAN}

\section{Stres dan Spiritualitas}

Hasil penelitian ini sejalan dengan Ningrum et.al terhadap 82 responden yang didapati $69,5 \%$ lansia memiliki tingkat spiritual yang baik dan 18,3\% memiliki tingkat stres sedang (Ningrum et al., 2016). Rofika juga menemukan bahwa lansia di UPT Bondowoso memiliki tingkat religi yang baik $(40,9 \%)$ dan tingkat stres sedang $(23,2 \%)$ (Rofika, S.R.; Azza, Awatiful; Rohmah, 2015).

Lansia memiliki kecenderungan mengalami stres akibat perubahan fungsi tubuhnya sehingga lansia merasa tidak mampu lagi melakukan aktivitas yang biasa dilakukannya. Selain itu, proses kehilangan seperti kehilangan pekerjaan karena masa pensiun, meninggalnya pasangan dan teman dekat, serta lebih rentan mengalami penyakit atau kekambuhan penyakit karena penurunan fungsi imun. Tingkat stres pada lansia berada pada level sedang karena lansia masih memiliki keluarga yang turut memperhatikan kebutuhan lansia dan menjadi sistem pendukung lansia secara psikologis dan emosional sehingga lansia mampu menangani kondisi stres yang dialaminya.

Mekanisme koping lain yang sering dilakukan lansia adalah dengan pendekatan spiritual (Letvak, 2006; Tuck and Alleyne, 2006). Sebagian besar lansia sudah mengalami masa pensiun dan tidak banyak melakukan kegiatan luar rumah sehingga lansia lebih memilih untuk melakukan banyak aktivitas keagamaan secara individual atau pun sosial di lingkungan tempat tinggalnya. Pendalaman agama yang diyakini, aplikasi makna atau perintah agama dalam kehidupan sehari-hari, dan mendekatkan diri kepada Tuhan merupakan fokus pada masa lansia (Werdel et al., 2014).

Hal ini terjadi karena lansia sudah mendapat pengalaman yang banyak mengenai hidupnya sehingga lansia menghubungkan makna dari peristiwa yang terjadi selama hidupnya dengan konsep spiritualitas yang dimilikinya. Selain itu, lansia juga mendalami spiritualitas untuk menghadapi takdir seperti kematian yang secara pasti akan dialaminya. Sehingga dari seluruh alasan itulah yang menyebabkan lansia mengambil komitmen yang sungguhsungguh terhadap aspek religiusitasnya.

\section{Hubungan Spiritualitas dan Stres}

Hasil penelitian ini didukung oleh Amir yang menemukan bahwa terdapat hubungan antara perilaku spiritual dengan tingkat stres lansia $(r=0,711 ; p<0,0001)$ di Bondowoso pada tahun 2014 (Amir \& Indriyani, 2011), dan didukung juga oleh Rofika di unit pelayanan lansia Bondowoso yang menyatakan terdapat hubungan signifikan antara aktivitas religi dengan tingkat stres lansia $(p=0,001)$ (Rofika, S.R., Azza, Awatiful; \& Rohmah, N., 2015).

Hal ini dipengaruhi oleh kesadaran diri lansia akan pentingnya spiritualitas di usia lanjut dan hal ini juga didukung dengan komitmen religius baik secara intrapersonal maupun interpersonal. Komitmen spiritual akan membentuk perilaku lansia dan kemudian tercermin dari aktivitas-aktivitas lansia dalam konteks keagamaan.

Penurunan tingkat stres lansia membuat lansia tidak mudah mengalami depresi, bahkan rendahnya tingkat stres juga berdampak pada tingkat depresi yang rendah. Hal ini nampak pada hasil penelitian Mustiadi pada lansia di unit rehabilitasi sosial di Ungaran Semarang bahwa terdapat hubungan signifikan antara aktivitas spiritual dengan tingkat depresi lansia ( $\mathrm{p}=0,022)$ (Mustiadi, 2014).

Spiritualitas dapat memberikan jawaban atas rangkaian peristiwa yang dialami lansia dan dianggap dapat memberikan pemahaman bahwa kehidupan sungguh berharga dan begitu juga dengan kematian. Spiritualitas juga memicu 
terjadinya stimulasi munculnya perasaan optimis, keyakinan, dan harapan secara positif pada banyak situasi bahkan kondisi yang sulit dan menakutkan (Langer, 2004; Moon \& Kim, 2013). Tingkat spiritualitas juga dapat memampukan lansia memiliki kontrol diri yang baik sehingga dapat membentuk gaya hidup yang baik. Selain itu, komunitas spiritual dapat menjadi sistem pendukung yang menyokong lansia ketika mengalami masalah dan membutuhkan jalan keluar atau bantuan atas masalah yang dihadapinya.

\section{KESIMPULAN}

Sebagian besar lansia dalam penelitian ini memiliki tingkat spiritualitas yang sedang dan tingkat stres sedang. Selain itu, hasil penelitian ini mengungkapkan bahwa semakin tinggi tingkat spiritualitas maka tingkat stres lansia akan semakin rendah.

Oleh karena itu, edukasi dan pendampingan pasien lansia dengan mendorong dalam meningkatkan kegiatan ibadah; membaca, mempelajari, dan merenungkan kitab suci; serta meningkatkan interaksi sosial dengan orang lain dalam kegiatan dan aktivitas keagamaan dapat menjadi strategi dalam intervensi keperawatan yang diberikan perawat sehinggaasuhan yang diberikan lebih holistik.

Asuhan keperawatan spiritual juga dapat lebih ditekankan pada tiap topik mata ajar dalam institusi keperawatan sebagai suatu bentuk asuhan yang komprehensif dan holistik. Selain itu, penelitian selanjutnya dapat mencari variabel dependen lain yang dapat berhubungan atau dipengaruhi oleh kondisi spiritualitas pasien.

\section{DAFTAR PUSTAKA}

Alligood, M. R. (2014). Nursing Theorists and Their Work (8th edn). Elsevier Mosby. https://doi.org/10.5172/conu.2007.24. $1.106 \mathrm{a}$

Amir, F., \& Indriyani, D. (2011). Hubungan
Perilaku Spiritual dengan Tingkat Stres pada Lansia di Dusun Lumbung desa Bataan Kecamatan Tenggarang Bondowoso, (13), 1-12. Retrieved from http://digilib.unmuhjember.ac.id/files/ disk1/67/umj-1x-faisalamir-3347-1manuskri-f.pdf

Conner, O. (2012). The Religious Commitment Inventory-10. Retrieved from www.midss.ie

Kemenkes RI. (2017). Analisis Lansia di Indonesia. Retrieved from https://jakartaevent.co.id/event/semina r-nasional-kesehatan-masyarakat-umjjakarta/

Langer, N. (2004). Resiliency and spirituality: Foundations of strengths perspective counseling with the elderly. Educational Gerontology, 30(7), 611-617. https://doi.org/10.1080/036012704904 67038

Letvak, S. (2006). Commentary on "Spirituality and Stress Management in Healthy Adults ."

Litbangkes Kemenkes RI. (2013). Riset Kesehatan Dasar, 1-306. https://doi.org/1 Desember 2013

Moon, Y. S., \& Kim, D. H. (2013). Association between religiosity/spirituality and quality of life or depression among living-alone elderly in a South Korean city. AsiaPacific Psychiatry, 5, 293-300. https://doi.org/10.1111/appy.12025

Mustiadi. (2014). Hubungan Aktivitas Spiritual Dengan Tingkat Depresi Pada Lanjut Usia Di Unit Rehabilitasi Sosial Wening Wardoyo, 1-9.

Ningrum, D. P., \& Suhariyanti, E. (2016). Hubungan tingkat spiritualitas dengan tingkat stres di Desa Ngargomulyo Magelang, 6-21.

Perez-Blasco, J., Sales, A., Melendez, J. C., \& Mayordomo, T. (2016). The Effects of Mindfulness and Self-Compassion on Improving the Capacity to Adapt to Stress Situations in Elderly People Living in the Community. Clinical Gerontologist, 39(2), 90-103. https://doi.org/10.1080/07317115.201 5.1120253 
Rofika, S.R.; Azza, Awatiful; Rohmah, N. (2015). Hubungan aktivitas religi dengan tingkat stres lansiadi UPT pelayanan sosial lanjut usia Bondowoso, 001, 1-13. Retrieved from

http://digilib.unmuhjember.ac.id/files/ disk1/70/umj-1x-sitirisaro-3491-1artikel-l.pdf

Tuck, I., \& Alleyne, R. (2006). Spirituality and Stress Management in Healthy Adults, 245-253.

Werdel, M. B., Dy-Liacco, G. S., Ciarrocchi, J. W., Wicks, R. J., \& Breslford, G. M. (2014). The Unique Role of Spirituality in the Process of Growth Following Stress and Trauma. Pastoral Psychology, 63(1),57-71. https://doi.org/10.1007/s11089-0130538-4 